\title{
HUBUNGAN TINGKAT PENGETAHUAN SIKAP DAN \\ KETERSEDIAAN SARANA DENGAN TINDAKAN \\ PENGGUNAAN ALAT PELINDUNG DIRI \\ PADA PETUGAS PENGANGKUT SAMPAH \\ Studi Dilakukan di Dinas Lingkungan Hidup \\ Kabupaten Tabanan Tahun 2021
}

\section{Ni Wayan Astiti Rahayu', Ni Made Marwati², I Gusti Ayu Made Aryasih}

\begin{abstract}
Occupational health efforts are aimed at protecting workers from accidents and occupational diseases. Workers and other people entering the workplace are required to use PPE in accordance with the potential hazards. This study aims to determine the relationship between the level of knowledge, attitudes, and availability of facilities with the use of personal protective equipment. This type of research is an analytical survey with a Cross Sectional approach. Respondents were 85 officers at the Tabanan Regency Environmental Service. Data collection using questionnaires and observation sheets. The results obtained are p-value 0.000 which indicates that the $p$ value < (0.05) which means Ho is rejected or there is a significant relationship. The CC value to show the close relationship between knowledge and action is 0.439, which means there is a strong relationship. The close relationship between attitudes and actions shows a $C C$ value of 0.634 which indicates a very strong relationship. The relationship between the availability of PPE facilities and the CC value is 0.619, which means that there is a very strong relationship. For the Environment Agency to provide sufficient PPE so that officers can apply the use of PPE when working in order to minimize the occurrence of work accidents.
\end{abstract}

Keywords: Knowledge, Attitude, Action, Personal Protective Equipment

\section{PENDAHULUAN}

Jumlah penduduk Indonesia

yang besar dengan tingkat

pertumbuhan yang tinggi

mengakibatkan bertambahnya

volume sampah. Disamping itu, pola

konsumsi masyarakat memberikan

kontribusi dalam menimbulkan jenis

sampah yang semakin beragam ${ }^{1}$.
Menurut Sejati (2009), mengatakan bahwa peningkatan jumlah penduduk dan gaya hidup sangat berpengaruh pada volume sampah. Karakter sampah di perkotaan sangat dipengaruhi oleh tingkat pertumbuhan penduduk, pertumbuhan ekonomi dan 
kemakmuran, serta gaya hidup masyarakat perkotaan.

Peneliti Sustainable Waste Indonesia (SWI) Dini Trisyanti menyampaikan, pandemi Corona sedikit banyak mempengaruhi kelangsungan pengelolaan sampah di Indonesia. Pasalnya, pemulung serta pekerja sektor informal pengelolaan sampah lainnya terbilang rentan terdampak pada kondisi saat ini ${ }^{2}$.

Penggunaan alat pelindung perorangan merupakan salah satu alternatif untuk melindungi pekerja dari bahaya-bahaya kesehatan. Namun perlu diperhatikan bahwa alat pelindung perorangan harus sesuai dan adekuat untuk bahaya-bahaya tertentu, resisten terhadap kontaminan-kontaminan udara, dibersihkan dan dipelihara dengan baik, serta sesuai untuk pekerja yang memakainya. Untuk alat-alat tertentu seperti alat pelindung pernapasan, sumbat/tutup telinga, pakaian kerja kedap air, dan lain-lain mungkin tidak nyaman untuk dipakai terutama di cuaca yang panas. Jadi, mungkin diperlukan pengurangan jam kerja paling tidak, pada waktu-waktu yang memerlukan pemakaian alat pelindung tersebut ${ }^{3}$.
Hasil pengamatan awal pada petugas pengangkut sampah, nampak beberapa petugas tidak menggunakan alat pelindung diri pada saat proses pemindahan sampah dari tempat pembuangan sampah sementara ke truk pengangkutan sampah dan beberapa ada yang menggunakan baju lengan panjang, masker, dan sarung tangan. Saat diwawancarai, petugas memiliki beberapa alasan mengapa alat pelindung diri tidak digunakan semaksimal mungkin, diantaranya yaitu masalah kenyamanan saat bekerja dan merasa sangat yakin akan tetap aman walaupun tanpa alat pelindung diri. Pekerja pengangkut sampah ini melakukan tugasnya setiap hari, yaitu mengumpulkan sampah dan dibawa ketempat pembuangan khusus. Pekerjaan ini lebih berisiko dibandingkan dengan pekerja kebersihan lainnya seperti tenaga sapu, operator alat berat, maupun supir truk pengangkut sampah karena berhubungan langsung dengan sampah atau berbagai macam kotoran.

Berdasarkan dari uraian latar belakang tersebut, peneliti ingin mengetahui hubungan tingkat 
pengetahuan dan sikap dengan tindakan penggunaan alat pelindung diri pada petugas pengangkut sampah di Kabupaten Tabanan. Diharapkan dengan dilakukannya kegiatan penelitian ini, pihak Dinas Lingkungan Hidup Kabupaten Tabanan menjadi semakin baik dalam penyediaan alat pelindung diri serta menambah wawasan petugas pengangkut sampah mengenai penggunaan alat pelindung diri.

\section{METODE PENELITIAN}

Jenis penelitian ini adalah penelitian survei analitik dengan pendekatan Cross Sectional yang berlokasi di Dinas Lingkungan Hidup Kabupaten Tabanan. Sampel dalam penelitian ini adalah seluruh populasi petugas pengangkut sampah di Dinas Lingkungan Hidup Kabupaten Tabanan dengan jumlah 85 responden yang dipilih secara jenuh yang dimana sampel ditentukan bila semua anggota populasi digunakan sebagai sampel, penelitian yang ingin membuat generalisasi dengan kesalahan yang sangat kecil. Penggunaan teknik ini digunakan karena jumlah populasi relatif kecil yaitu 85 orang, dengan
21 rute pengangkutan sampah. Jenis data yang dikumpulkan dalam penelitian ini berupa data primer dan data sekunder.

Adapun cara pengumpulan data melalui wawancara dengan menggunakan kuesioner untuk pengumpulan data pengetahuan, sikap dan ketersediaan sarana APD responden, sedangkan lembar observasi untuk pengumpulan data tindakan petugas pengangkut sampah tentang penggunaan alat pelindung diri yang disusun oleh peneliti dan diisi oleh responden sesuai dengan panduan yang tepat dalam proses menjawab pertanyaan yang ada dalam kuesioner. Alternatif yang peneliti lakukan untuk pengumpulan data di masa pandemi yaitu dengan metode daring menggunakan media berupa google formulir, dimana kuesioner disebar ke seluruh responden melalui WhatsApp Group yang telah dikoordinasikan dengan Kasi Pengelolaan Sampah di Dinas Lingkungan Hidup Kabupaten Tabanan sebagai upaya pencegahan penyebaran virus COVID-19. 
HASIL DAN PEMBAHASAN

\section{Analisis Univariate}

Analisis ini juga disebut analisis deskriptif yang bertujuan untuk menjelaskan karakteristik setiap variabel penelitian.

Distribusi pengetahuan responden digambarkan seperti pada tabel 1:

Tabel 1

Distribusi Pengetahuan Petugas Pengangkut Sampah di Dinas Lingkungan Hidup Kabupaten Tabanan Tahun 2021

\begin{tabular}{lcc}
\hline Pengetahuan & Jumlah & $\%$ \\
\hline Baik & 30 & 35,3 \\
Sedang & 30 & 35,3 \\
Buruk & 25 & 29,4 \\
\hline Total & 85 & 100 \\
\hline
\end{tabular}

Berdasarkan tabel 1 di atas dapat dilihat bahwa responden yang memiliki pengetahuan buruk berjumlah 25 orang $(29,4 \%)$. Dapat dinyatakan bahwa lebih banyak responden yang memiliki pengetahuan baik dan sedang dibandingkan dengan yang buruk. Pengetahuan adalah hasil dari tahu dan terjadi setelah seseorang melakukan pengindraan terhadap suatu objek tertentu. Pengindraan terjadi melalui panca indra manusia yang sebagian besar diperoleh melalui mata dan telinga ${ }^{4}$. Berdasarkan teori ini telah sesuai dengan yang terjadi di lapangan dimana petugas pengangkut sampah belajar dengan melihat berbagai media dan mendengan informasi mengenai hal-hal yang menyangkut tentang pekerjaannya.

Distribusi sikap responden digambarkan seperti pada tabel 2:

Tabel 2

Distribusi Sikap Petugas Pengangkut Sampah di Dinas Lingkungan Hidup Kabupaten Tabanan Tahun 2021

\begin{tabular}{lcc}
\hline \multicolumn{1}{c}{ Sikap } & Jumlah & $\%$ \\
\hline Baik & 21 & 24,7 \\
Sedang & 26 & 30,6 \\
Buruk & 38 & 44,7 \\
\hline Total & 85 & 100 \\
\hline
\end{tabular}

Berdasarkan tabel 2 di atas dapat dilihat bahwa responden yang memiliki sikap buruk berjumlah 38 orang $(44,7 \%)$. Variabel pengganggu 
yang mempengaruhi sikap yaitu pendidikan, dimana korelasinya $0,022<0,05$ yang menyatakan adanya hubungan antara sikap dengan pendidikan petugas pengangkut sampah.

Berdasarkan teori yang dikemukakan oleh Notoatmodjo, 2010 dinyatakan bahwa sikap adalah respons tertutup seseorang terhadap stimulus atau objek tertentu yang sudah melibatkan faktor pendapat dan emosi dari yang bersangkutan, selain itu dinyatakan pula bahwa sikap itu tidak dapat dilihat, tetapi hanya bisa ditafsirkan terlebih

dahulu, komponen di dalamnya yaitu kepercayaan, kehidupan emosional, dan kecenderungan untuk bertindak. Jika dilihat dari hasil yang didapat maka responden memiliki kepercayaan yang baik dalam hal menjaga keselamatan kerjanya dengan menggunakan APD yang dapat dilihat dari pengetahuannya namun belum memiliki kecenderungan untuk bertindak karena sikap adalah ancang-ancang untuk bertindak atau berperilaku terbuka (tindakan) ${ }^{5}$.

Distribusi ketersediaan sarana APD digambarkan seperti pada tabel 3:

Tabel 3

Distribusi Ketersedian Sarana APD Petugas Pengangkut Sampah di Dinas Lingkungan Hidup Kabupaten Tabanan Tahun 2021

\begin{tabular}{|c|c|c|}
\hline Ketersediaan Sarana & Jumlah & $\%$ \\
\hline Baik & 14 & 16,5 \\
\hline Sedang & 28 & 32,9 \\
\hline Buruk & 43 & 50,6 \\
\hline Total & 85 & 100 \\
\hline
\end{tabular}

Berdasarkan tabel 3 di atas dapat dilihat bahwa responden yang memiliki ketersediaan sarana buruk berjumlah 43 orang $(50,6)$. Hasil ini menunjukkan bahwa ketersediaan sarana alat pelindung diri di lingkungan kerja Dinas Lingkungan Hidup Kabupaten Tabanan masih sangat kurang untuk digunakan dalam melakukan pekerjaan setiap harinya, sebab pemberian sarana alat pelindung diri berupa berupa masker, sarung tangan, topi, sepatu, dan baju seragam hanya 1 tahun sekali.

Alat Pelindung Diri selanjutnya disingkat APD adalah suatu alat yang mempunyai kemampuan untuk melindungi 
seseorang yang fungsinya mengisolasi sebagian atau seluruh tubuh dari potensi bahaya di tempat kerja. APD wajib digunakan ditempat kerja di mana dilakukan pengangkutan barang, binatang atau

\section{Tabel 4}

Distribusi Tindakan Penggunaan APD pada Petugas Pengangkut Sampah di Dinas Lingkungan Hidup Kabupaten Tabanan Tahun 2021 manusia, baik di daratan, melalui terowongan, di permukaan air, dalam air maupun di udara APD ${ }^{6}$.

Distribusi tindakan responden digambarkan seperti pada tabel 4:

\begin{tabular}{rcc}
\hline Tindakan & Jumlah & $\%$ \\
\hline Sudah melakukan & 27 & 31,8 \\
Tidak melakukan & 58 & 68,2 \\
\hline Total & 85 & 100 \\
\hline
\end{tabular}

Berdasarkan tabel 4 di atas dapat dilihat bahwa responden dengan kategori tidak melakukan berjumlah 58 orang $(68,2 \%)$. Variabel pengganggu yang mempengaruhi tindakan yaitu masa kerja, dimana korelasinya 0,049 < 0,05 yang menyatakan adanya hubungan antara tindakan dengan masa kerja petugas pengangkut sampah.

Definisi tindakan adalah mekanisme dari suatu pengamatan yang muncul dari persepsi sehingga ada respon untuk mewujudkan suatu tindakan. Dalam kamus bahasa Indonesia, praktik/ tindakan adalah pelaksanaan, perbuatan dari teori. Jadi praktik adalah cara melaksanakan secara nyata apa yang 
Hasil uji analisis hubungan pengetahuan dengan tindakan ditunjukkan dengan tabel 5 dibawah ini:

Tabel 5

Uji Analisis Hubungan Pengetahuan dengan Tindakan Petugas Pengangkut

Sampah di Dinas Lingkungan Hidup Kabupaten Tabanan Tahun 2021

\begin{tabular}{|c|c|c|c|c|c|c|c|c|}
\hline \multirow{3}{*}{ Pengetahuan } & \multicolumn{4}{|c|}{ Tindakan } & \multirow{2}{*}{\multicolumn{2}{|c|}{ Jumlah }} & \multirow{3}{*}{$\mathrm{p}$} & \multirow{3}{*}{$\mathrm{CC}$} \\
\hline & \multicolumn{2}{|c|}{ Sudah melakukan } & \multicolumn{2}{|c|}{ Tidak melakukan } & & & & \\
\hline & $\mathrm{F}$ & $\%$ & $\mathrm{~F}$ & $\%$ & $\mathrm{~F}$ & $\%$ & & \\
\hline Baik & 17 & 56,7 & 13 & 43,3 & 30 & 100 & & \\
\hline Sedang & 10 & 33,3 & 20 & 66,7 & 30 & 100 & 0,000 & 0,439 \\
\hline Buruk & 0 & 0,0 & 25 & 100 & 25 & 100 & & \\
\hline Jumlah & 27 & 31,8 & 58 & 68,2 & 85 & 100 & & \\
\hline
\end{tabular}

Berdasarkan interpretasi tabel 5 di atas didapatkan hasil bahwa responden dengan pengetahuan buruk, seluruhnya masuk dalam kategori tidak melakukan tindakan penggunaan alat pelindung diri yang berjumlah 25 orang (100\%).

Berdasarkan hasil analisis data menggunakan uji chi square diperoleh nilai asymp.sig (2-sided) sebesar 0,000. Karena nilai asymp.sig (2-sided) $0,000<0,05$. Maka dapat disimpulkan bahwa $\mathrm{H} 0$ ditolak dan $\mathrm{Ha}$ diterima. Hal ini berarti ada Hubungan Pengetahuan Dengan Tindakan Penggunaan Alat Pelindung Diri pada Petugas Pengangkut Sampah di Dinas Lingkungan Hidup Kabupaten Tabanan Tahun 2021. Untuk melihat kuat lemahnya hubungan dilihat dari nilai coefficient contigensi (CC) yaitu
0,439 . Nilai tersebut menunjukkan hubungan yang kuat antara variabel pengetahuan dengan tindakan petugas pengangkut sampah dalam penggunaan alat pelindung diri.

Hasil ini masih sejalan dengan penelitian ${ }^{8}$ bahwa ada hubungan antara pengetahuan dengan penggunaan alat pelindung diri dengan nilai ( $p$-value $=0,003)$. Penelitian ini sejalan dengan penelitian ${ }^{9}$ bahwa terdapat hubungan antara tingkat pengetahuan dengan kepatuhan dalam menggunakan alat pelindung diri pada pekerja pengangkut sampah di wilayah Subak Desa Kenderan dengan nilai signifikan $<0,05$ ( $p$-value $=0,000)$.

Berdasarkan hasil penelitian, digabungkan dengan teori dan penelitian terkait. Peneliti berpendapat bahwa ada hubungan 
yang signifikan antara pengetahuan dengan tindakan penggunaan APD di Dinas Lingkungan Hidup Kabupaten Tabanan. Tingkat pengetahuan yang tinggi tentang APD bukanlah jaminan responden memiliki kemampuan sesuai tingkat pengetahuannya. tingkatan pengetahuan seseorang terdiri dari enam domain yaitu tahu, paham, aplikasi, analisis, sinntesis dan evaluasi. Setiap tingkatan memperlihatkan kemampuan individu. Tingginya domain pengetahuan responden dapat dilihat seberapa tinggi sikap dan perilaku responden menggunakan APD ketika praktik. Tingkat pengetahuan yang tinggi pada responden terhadap APD dapat dipengaruhi oleh beberapa faktor diantaranya faktor lingkungan responden serta pendidikan responden. Kondisi lingkungan belajar responden dapat mempengaruhi pengetahuan responden terhadap APD.

Hasil uji analisis hubungan sikap dengan tindakan ditunjukkan dengan tabel 6 dibawah ini:

Tabel 6

Uji Analisis Hubungan Sikap dengan Tindakan Petugas Pengangkut Sampah di Dinas Lingkungan Hidup Kabupaten Tabanan Tahun 2021

\begin{tabular}{lcccccccc}
\hline \multirow{1}{*}{ Sikap } & \multicolumn{9}{c}{ Tindakan } & \multirow{2}{*}{$\begin{array}{c}\text { Sudah } \\
\text { melakukan }\end{array}$} & \multicolumn{2}{c}{ Tidak melakukan } & Jumlah & p & CC \\
\cline { 2 - 7 } & F & $\%$ & F & $\%$ & F & $\%$ & & \\
\hline Baik & 20 & 95,2 & 1 & 4,8 & 21 & 100 & & \\
Sedang & 7 & 26,9 & 19 & 73,1 & 26 & 100 & 0,000 & 0,634 \\
Buruk & 0 & 0,0 & 38 & 100 & 38 & 100 & & \\
\hline \multicolumn{1}{c}{ Jumlah } & 27 & 31,8 & 58 & 62,2 & 85 & 100 & & \\
\hline
\end{tabular}

Berdasarkan interpretasi tabel

6 diatas di dapatkan hasil bahwa responden yang memiliki sikap buruk seluruhnya tidak melakukan tindakan penggunaan alat pelindung diri yang berjumlah 38 orang $(100 \%)$.

Berdasarkan hasil analisis data menggunakan uji chi square diperoleh nilai asymp.sig (2-sided) sebesar 0,000. Karena nilai asymp.sig (2-sided) $0,000<0,05$. Maka dapat disimpulkan bahwa $\mathrm{HO}$ ditolak dan $\mathrm{Ha}$ diterima. Hal ini berarti ada Hubungan Sikap Dengan Tindakan Penggunaan Alat Pelindung Diri pada Petugas Pengangkut Sampah di Dinas 
Lingkungan Hidup Kabupaten

Tabanan Tahun 2021. Untuk melihat kuat lemahnya hubungan dilihat dari nilai coefficient contigensi (CC) yaitu 0,634. Nilai tersebut menunjukkan hubungan yang sangat kuat antara variabel sikap dengan tindakan petugas pengangkut sampah dalam penggunaan alat pelindung diri.

Praktik atau tindakan, merupakan suatu sikap tidak secara otomatis terwujud dalam suatu tindakan (overt behavior). Untuk mewujutkan sikap menjadi perbuatan nyata, diperlukan faktor pendukung atau kondisi yang memungkinkan, antara lain fasilitas. Terdapat tingkatan praktik diantaranya persepsi, respon terpimpin, mekanisme, dan adaptasi ${ }^{4}$.

Secara umum, dalam berbagai referensi sikap memiliki 3 komponen yakni kognitif, afektif, dan kecenderungan tindakan (konatif) yang merupakan suatu kesatuan sistem, sehingga tidak dapat dilepas satu dengan lainnya. Ketiga komponen tersebut secara bersama pelindung diri dalam melakukan pekerjaannya sehari-hari karena dilihat dari definisinya sikap sebagai suatu pola perilaku untuk membentuk sikap pribadi. Sikap seseorang terhadap suatu obyek atau subyek dapat positif atau negatif. Menifestasi sikap terlihat dari tanggapan seseorang apakah ia menerima atau menolak, setuju atau tidak setuju ${ }^{10}$.

Selaras dengan hasil penelitian ${ }^{11}$ didapatkan hasil uji statistik yang menunjukkan angka $p$ value sebesar 0,014 yaitu ada hubungan yang signifikan antara sikap dengan pengunaan APD. Selain itu penelitian ini juga sejalan dengan 12 dimana hasil analisis hubungan sikap dengan tindakan petugas kebersihan berdasarkan uji statistik chi square didapatkan hasil $p$-value $=0,031$ hasil menunjukan bahwa nilai $\mathrm{p}<\mathrm{a}(0.05)$ yang berarti Ho ditolak atau ada hubungan yang bermakna/signifikan antara sikap dengan tindakan responden.

Berdasarkan hasil penelitian, teori dan penelitian terkait, peneliti berasumsi bahwa jika seseorang bersikap baik maka berpengaruh juga pada tindakan pengunaan alat menyesuaikan diri dalam situasi social dalam hal ini pekerjaan mengangkut 
sampah, atau secara sederhana sikap adalah respon terhadap stimuli social yang telah dikondisikan.
Hasil uji analisis hubungan ketersediaan sarana APD dengan tindakan ditunjukkan dengan tabel 7 dibawah ini:

Tabel 7

Uji Analisis Hubungan Ketersediaan Sarana dengan Tindakan Petugas Pengangkut Sampah di Dinas Lingkungan Hidup Kabupaten Tabanan Tahun 2021

\begin{tabular}{lcccccccc}
\hline \multirow{1}{*}{ Sikap } & \multicolumn{9}{c}{$\begin{array}{c}\text { Sudah } \\
\text { melakukan }\end{array}$} & \multicolumn{2}{c}{ Tidak melakukan } & Jumlah & p & CC \\
\cline { 2 - 6 } & $\mathrm{F}$ & $\%$ & $\mathrm{~F}$ & $\%$ & $\mathrm{~F}$ & $\%$ & & \\
\hline Baik & 14 & 100 & 0 & 0,0 & 14 & 100 & & \\
Sedang & 13 & 46,4 & 15 & 53,6 & 28 & 100 & 0,000 & 0,619 \\
Buruk & 0 & 0,0 & 43 & 100 & 43 & 100 & & \\
\hline \multicolumn{1}{c}{ Jumlah } & 27 & 31,8 & 58 & 68,2 & 85 & 100 & & \\
\hline
\end{tabular}

\section{Berdasarkan interpretasi tabel}

7 diatas di dapatkan hasil bahwa responden yang memiliki kategori ketersediaan sarana buruk seluruhnya tidak melakukan tindakan penggunaan alat pelindung diri yang berjumlah 43 orang (100\%).

Berdasarkan hasil analisis data menggunakan uji chi square diperoleh nilai asymp.sig (2-sided) sebesar 0,000. Karena nilai asymp.sig (2-sided) 0,000 $<0,05$. Maka dapat disimpulkan bahwa $\mathrm{H} 0$ ditolak dan $\mathrm{Ha}$ diterima. Hal ini berarti ada Hubungan Ketersediaan Sarana Dengan Tindakan Penggunaan Alat Pelindung Diri pada Petugas Pengangkut Sampah di
Dinas Lingkungan Hidup Kabupaten Tabanan Tahun 2021. Untuk melihat kuat lemahnya hubungan dilihat dari nilai coefficient contigensi (CC) yaitu 0,619. Nilai tersebut menunjukkan hubungan yang sangat kuat antara variabel ketersediaan sarana dengan tindakan petugas pengangkut sampah dalam penggunaan alat pelindung diri.

Alat Pelindung Diri adalah alat-alat yang mampu memberikan perlindungan terhadap bahayabahaya kecelakaan. Atau bisa juga disebut alat kelengkapan yang wajib digunakan saat bekerja sesuai bahaya dan risiko kerja untuk menjaga keselamatan pekerja itu sendiri dan 
orang di sekelilingnya. Namun demikian, APD tidak menghilangkan ataupun mengurangi bahaya yang ada. Peralatan ini hanya mengurangi jumlah kontak dengan bahaya dengan cara penempatan penghalang antara tenaga kerja dengan bahaya. Penggunaan APD sangat penting bagi para pekerja, terutama untuk mencegah penyakit akibat kerja ataupun kecelakaan kerja $^{13}$.

Hasil penelitian ini sejalan dengan penelitian ${ }^{14}$ dimana hasil analisis hubungan ketersediaan alat pelindung diri dengan penggunaan alat pelindung diri pada pengangkut sampah di Wilayah Kecamatan Ilir Timur 1 Dinas Lingkungan Hidup dan Kebersihan Kota Palembang diperoleh hasil uji statistik dengan $p$ value $=0,021<\alpha$ yang dapat disimpulkan bahwa ada hubungan yang signifikan antara ketersediaan sarana dengan penggunaan alat pelindung diri pada pekerja pengangkut sampah.

Berdasarkan hasil penelitian, digabungkan dengan teori dan penelitian terkait. Peneliti berpendapat bahwa ada hubungan yang signifikan antara ketersediaan sarana APD dengan tindakan penggunaan APD. Ketersediaan sarana merupakan salah satu faktor yang mempengaruhi terbentuknya tindakan penggunaan APD. Ketersediaan alat pelindung diri di tempat kerja harus menjadi perhatian pihak manajemen untuk mendorong terjadinya perubahan sikap. Semua fasilitas alat pelindung diri yang diwajibkan pada tenaga pekerja harus tersedia sesuai dengan risiko bahaya yang ada di tempat kerja. Sarana APD yang lengkap dapat mendukung pembentukan perilaku yang baik dalam menjalankan prosedur dalam bekerja, dalam penelitian ini adalah penggunaan APD. Berdasarkan hasil wawancara, petugas pengangkut sampah APD harus di beli sendiri sehingga memberatkan pekerja itu sendiri. Karena pihak perusahaan hanya memberikan APD 1 tahun sekali dengan jumlah yang tidak mencukupi.

\section{SIMPULAN}

Berdasarkan hasil dan pembahasan yang telah diuraikan makan dapat disimpulkan bahwa hubungan pengetahuan, sikap, ketersediaan sarana dengan tindakan 
penggunaan alat pelindung diri pada petugas pengangkut sampah di Dinas Lingkungan Hidup Kabupaten Tabanan Tahun 2021 menggunakan uji Chi square dengan p-value 0,000 menunjukkan bahwa nilai $\mathrm{p}<\mathrm{a}$ (0.05) yang berarti Ho ditolak atau ada hubungan yang signifikan antar variabelnya.

\section{SARAN}

Adapun saran yang dapat peneliti berikan bagi DLH Kabupaten Tabanan yaitu agar memberikan sarana alat pelindung diri yang sesuai standar minimal berupa topi, masker bedah (surgical mask), sarung tangan kedap air pakaian kerja dengan lengan panjang, serta sepatu boots kedap air, dengan jumlah dan jangka waktu tertentu agar mencukupi untuk digunakan bekerja sehari-hari. Kepada petugas pengangkut sampah yang telah melakukan tindakan penggunaan alat pelindung diri agar tetap dipertahankan dan untuk yang belum melakukan tindakan penggunaan alat pelindung diri agar kedepannya mulai memperhatikan hal ini untuk meminimalisir terjadinya penyakit akibat kerja
(PAK) ataupun kecelakaan akibat kerja (KAK).

\section{DAFTAR PUSTAKA}

1. RI, P. Undang-Undang Republik Indonesia Nomor 18 Tahun $2008 \quad$ tentang Pengelolaan Sampah. (2008).

2. Andi, D. Pandemi Corona Bisa Menghambat Pengelolaan Sampah Plastik di Indonesia. Kontan.co.id (2019).

3. Sumantri, A. Kesehatan Lingkungan. (Prenada Media Group, 2015).

4. Notoatmodjo, S. Promosi Kesehatan dan Ilmu Perilaku. (Rineka Cipta, 2007).

5. Notoatmodjo, S. Promosi Kesehatan Teori dan Aplikasi. (Rineka Cipta, 2010).

6. Permenakertrans. Peraturan Menteri Tenaga Kerja dan Transmigrasi Nomor PER.08/MEN/VII/2010

Tentang Alat Pelindung Diri. (2010).

7. Habibi, Widiastuty, L. \& Hidayat, G. Gambaran Perilaku Petugas Pengangkut Sampah dalam Penerapan 
Kesehatan dan Keselamatan

Kerja di Kecamatan Tallo

Kota Makassar. Higiene 5, 60-65 (2019).

8. Satriadi, A. F. Analisis Faktorfaktor yang Berhubungan dengan Perilaku Penggunaan Alat Pelindung Diri (APD) pada Pekerja Pengangkut Sampah di Dinas Lingkungan Hidup Kebersihan dan Keindahan Kota Banda Aceh. Fak. Kesehat. Masy. Univ. Muhammadiyah Aceh (2020).

9. Darmayanti. Hubungan Tingkat Pengetahuan dan Sikap dengan Kepatuhan dalam Menggunakan Alat Pelindung Diri pada Pekerja Pengangkut Sampah di Wilayah Subak Desa Kenderan. (2015).

10. Mufida, S. Kajian Teori Sikap. (2014).

11. Agustina, R., Kamaluddin \& Dahlan, H. Determinan Penggunaan Alat Pelindung Diri pada Pekerja Pengangkut Sampah di Dinas Lingkungan
Hidup dan Kebersihan Kota Palembang. 2, 20-28 (2019).

12. Desiani, K. A. Hubungan Tingkat Pengetahuan, Sikap dengan Tindakan Pengunaan APD Petugas Kebersihan di Dinas Lingkungan Hidup Kabupaten Gianyar. (2020).

13. Lisnawati, Y., Raksanagara, A. S. \& Yunita, S. Faktrfaktor yang Berhubungan dengan Kepatuhan Penggunaan Alat Pelindung Diri (APD) serta Kaitannya terhadap Status Kesehatan pada Petugas Pengumpul Sampah Rumah Tangga di Kota Tasikmalaya. J. Kesehat. Bakti Tunas Husada 13, (2015).

14. Sa'adah, K. Analisis Penggunaan Alat Pelindung Diri (APD) pada Pekerja Pengangkut Sampah di Wilayah Kecamatan Ilir Timur 1 Dinas Lingkungan Hidup dan Kebersihan Kota Palembang. J. Stikes Bina Usada (2020). 